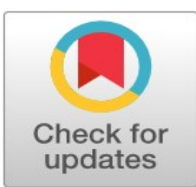

\title{
Correlation of growth and IAA production of Lysinibacillus Fusiformis UD 270
}

\author{
Huynh Thi Thuy Hanh ${ }^{1}$, Wiyada Mongkolthanaruk ${ }^{2 *}$
}

\author{
${ }^{1,2}$ Department of Microbiology, Faculty of Science, Khon Kaen University, Khon Kaen, Thailand
}

\author{
Index Terms \\ Lysinibacillus Fusiformis \\ Indole-3-Acetic Acid \\ Tryptophan \\ Bacterial Growth
}

Received: 4 March 2017

Accepted: 3 June 2017

Published: 16 October 2017

\begin{abstract}
This study was investigated in IAA biosynthesis with different concentrations of tryptophan and bacterial cell number as well as observed the correlation between bacterial growth and IAA production. The bacteria were grown in nutrient broth supplemented with $0,0.5,1,2,3,4$, and $5 \mathrm{mg} \mathrm{mL}^{-1}$ of tryptophan at $30^{\circ} \mathrm{C}$ for $72 \mathrm{~h}$. Reasonable bacterial growth and IAA production were appreciably determined at $36 \mathrm{~h}$ of incubation in $5 \mathrm{mg} \mathrm{mL}^{-1}$ of tryptophan. Meanwhile, the $\mathrm{pH}$ of the culture media was gradually increased at the beginning and made stable after $36 \mathrm{~h}$. Moreover, when the cell concentration was varied from $10^{3}$ to $10^{9}$ Colony-Forming Unit ( $\mathrm{CFU}) \mathrm{mL}^{-1}$, the IAA production was significantly higher at high cell concentrations, concretely with $10^{7}$ and $10^{9} \mathrm{CFU} \mathrm{mL}^{-1}$. Also, a positive correlation between growth and IAA production was indicated in the two experiments. The results have referred to the suitable uses of tryptophan and cell number for bacterial growth and IAA biosynthesis of $L$. fusiformis UD 270 to apply for further researches. Plant Growth Promoting Bacteria (PGPB) have been considered as beneficial microorganisms that can promote plant growth by their potential mechanism, particularly Indole-3-Acetic Acid (IAA) production. Lysinibacillus fusiformis UD 270 isolated from local plants in Khon Kaen, Thailand, displayed its capability to produce IAA from tryptophan, well-known as its precursor.
\end{abstract}

(C) 2017 The Author(s). Published by TAF Publishing.

\section{INTRODUCTION}

Bacteria which can promote plant growth are called PGPB. This group includes either free-living form or endophytic form that has specific symbiotic relationships with plants [1]. PGPB are known as beneficial microorganisms and, when used in place of synthetic chemicals, are capable of improving plant growth through supply of plant nutrients. They may also help to sustain environment health and soil productivity $[2,3,4]$. Indeed, the plant growth promoting effect is mostly explained by the release of metabolites directly stimulating growth such as phosphate solubilization, nitrogen fixation, siderophore production and modulating phytohormone levels. The indirect promotion of plant growth is performed as biocontrol agents [1]. One of the mechanisms by which PGPB promote plant growth is the ability to produce plant hormones, such as auxins [5]. IAA is the most common natural auxin found in plants and has a positive effect on root growth [6]. IAA responds to cell division, root elongation, seed and tuber germination, rate of xylem and root development, and resistanace to stress conditons [1]. Up to $80 \%$ of rhizobacteria, both through colonization of the seed or root surfaces, can synthesize IAA and it is proposed that they act in conjunction with endogenous IAA in plants to stimulate cell proliferation and to enhance the host's uptake of minerals and nutrients from the soil [7] . Additionally, plant growth promoting bacteria can produce IAA from tryptophan, which is the main precursor molecule for IAA production in bacteria by tryptophan dependent biosynthetic pathways. The optimization of bacterial IAA production has been studied for several years, mainly in culture media with varying important factors as temperature, $\mathrm{pH}$, precursor concentration $[8,9,10]$ and inoculum sizes [11]. The optimal condition for IAA production is distinct of each bacterial specie. The previous

*Corresponding author: Wiyada Mongkolthanaruk

${ }^{\dagger}$ Email: wiymon@kku.ac.th 
researches showed that Lysinibacillus fusiformis, a grampositive, rod-shaped bacterium of the genus Lysinibacillus is a Plant Growth Promoting Endophytic Bacteria (PGPEB). The endophyte L. fusiformis had positive traits for most of plant growth promotion [12]. Moreover, the capability for phytohormone biosynthesis of L. fusiformis has been observed in the recent years. This bacterium could synthesize IAA from tryptophan as the main precursor [13]. It was also reported that $L$. fusiformis strain Ps7 could synthesize ABA, GA3, IAA [14] . Nevertheless, it seems that there is not much information about a correlation between growth and IAA biosynthesis of $L$. fusiformis in culture media containing tryptophan in terms of using suitable amount of tryptophan and cell number. These two factors are considered more reasonable to determine the optimal condition for IAA production because they directly affect the amount of synthesized IAA like the increasing of precursor or inoculum size could account for the increasing of IAA production, and indirectly influence on practical application like the suitable cell number is good for preparing and applying to field. Therefore, the aim of this study was to investigate the effects of various concentrations of L-tryptophan and bacterial cells on growth and IAA production together with the correlation between growth and IAA production in culture medium.

\section{LITERATURE REVIEW}

\section{A. Plant Growth Promoting Bacteria}

Soil is full of microscopic life forms including bacteria, fungi, actinomycetes, algae and protozoa. Among different microorganisms, bacteria are the most common (i.e., approximately 95\%) [1]. Soil bacteria have capabilities to survive and use a wide range of different substances as sources of nutrients. The bacterial distribution is around the roots of plants, i.e in the rhizosphere which is typically much greater than in the rest of the soil [15]. It can be explained that the presence of high levels of nutrients including amino acids, sugars, organic acids and other small molecules that are exuded from plant roots leads to the high bacterial concentration around the roots of plants. As rhizosphere bacteria use the exudates for their growth and metabolism $[15,16]$. The interaction between bacteria in soil and plants may be beneficial, harmful or neutral $[15,17]$. The bacteria that can promote plant growth, are called plant growth promoting bacteria, including either free-living form or endophytic form that has specific sym- biotic interaction with plants. There are different types of bacteria-plant interaction such as rhizospheric way (bacteria bind to the roots or seed surfaces), phyllospheric way (bacteria bind to leaf or stem surfaces), symbiotic way (bacteria are typically found in root nodules), or endophytic interaction (bacteria colonize inside the plant tissue) [18, $19,20,21]$. Although the differences between these bacteria, they still use the same mechanisms in promoting plant growth. PGPB may promote plant growth either through indirect mechanisms via antibiotics and lytic enzymes, competition, ethylene regulation, induced systemic resistance or direct mechanisms via facilitating resource acquisition including fixed nitrogen, iron and phosphate, and specifically modulating phytohormone levels such as auxin, cytokinin, gibberellin and ethylene [1].

L. fusiformis or Aerobacillus fusiformis, is a gram positive, rod-shaped, and non-motile bacterium. A bacterial cell is approximately 2.5-3.0 micrometers in length, and 0.5-0.9 micrometers in width. This bacterium grows well in range of temperature from $17-37^{\circ} \mathrm{C}, \mathrm{pH}$ from 6-9.5, and $\mathrm{NaCl}$ concentration of $2-7 \%$. It can produce inactive spherical endospores that resist to unfavourable living conditions [22]. The research of Vendan et al. [12] showed that the endophyte, L. fusiformis, had positive traits for most of plant growth promotion. This organism has also been the beneficial bacterium that is associated with Citrus roots, and could significantly reduce the population of viable Candidatus Liberibacter Asiaticus in Huanglongbing symptomatic on leaves [23]. In branch of Cacao plants, L. fusiformis was found as endophytic endospore-forming bacteria which have the potential biological control of cacao diseases [24]. Moreover, the capability for phytohormone biosynthesis of L. fusiformis has been observed in the recent years. It was reported that $L$. fusiformis strain Ps7 could synthesize ABA, GA3, IAA [14] while L. fusiformis strain SW13 could produce IAA via indole-3-acetonitrile pathway using tryptophan as a precursor for conversion [13] including L. fusiformis UD270 that could produce high amount of IAA in culture media supplemented with tryptophan [25].

\section{B. Study Condition for IAA Production in Culture Media of Some Bacteria}

Mohite [10] isolated and identified 5 IAA producing bacteria from banana, cotton maize and wheat rhizosphere as B. megaterium, Lactobacillus casei, B. subtilis, B. cereus and Lactobacillus acidophilus. The test for optimization of physical factors for IAA production was conducted in $\mathrm{pH}$ 
range of 5 to 9 , temperature range of 20 to $40^{\circ} \mathrm{C}$, tryptophan concentration range of $0.05 \%$ to $1.5 \%$. Maximum IAA production was found in the medium supplemented with $0.1 \%$ tryptophan for B. megaterium, Lactobacillus casei, B. subtilis, $1.5 \%$ for Lactobacillus acidophilus, and $0.05 \%$ B. cereus. Each strain had different optimal concentration of precursor for IAA production. Indeed, Bharucha et al. [9] found the suitable concentrations of L-tryptophan for IAA production of Pseudomonas putida UB1 was $0.2 \mathrm{mg} \mathrm{mL}^{-1}$ in range of 0.05 to $0.25 \mathrm{mg} \mathrm{mL}^{-1}$, and noticed that the IAA production was gradually increase with the increased of Ltryptophan concentration.

In another research, Tallapragada et al. [11] performed a study of IAA producing Burkholderia seminalis and its effect on tomato. The A response surface methodology was utilized to find the relationships between reasonable factor. The results showed that IAA production increased together with increasing of tryptophan concentration and inoculum sizes.

\section{METHODOLOGY}

\section{A. Preparation of Endophytic Bacterial Strain}

Lysinibacillus fusiformis UD270 isolated from local plants in Khon Kaen, Thailand, was grown in the $2 \mathrm{~mL}$ tube of nutrient broth medium (NB, $5 \mathrm{~g}$ beef extract, $3 \mathrm{~g}$ peptone in $1000 \mathrm{~mL}$ distilled water), incubated at $30^{\circ} \mathrm{C}$ with agitation at $150 \mathrm{rpm}$. After 24 hours, the culture was used as the starter for the next experiments. The growth of $1 \mathrm{~mL}$ 24 -hour culture was determined at $600 \mathrm{~nm}$ of optical density by a spectrophotometer. Cell number was aseptically determined by plate counting method. One milliliter of bacterial culture was added into $9 \mathrm{~mL}$ of $0.85 \% \mathrm{NaCl}(8.5 \mathrm{~g} \mathrm{NaCl}$ in $1000 \mathrm{~mL}$ distilled water) and 10 -fold serial dilutions to 10-5 were done and spread on nutrient agar medium (NA, $5 \mathrm{~g}$ beef extract, $3 \mathrm{~g}$ peptone, $15 \mathrm{~g}$ agar in $1000 \mathrm{~mL}$ distilled water). The bacterial colonies on inoculated NA plates were counted after incubating at $30^{\circ} \mathrm{C}$ for $24 \mathrm{~h}$. Bacterial growth measurement and colony counting were performed in triplicate.

\section{B. Determination of the Optimal Tryptophan Concentra- tion for Bacterial IAA Biosynthesis}

For finding the suitable concentration of Ltryptophan for IAA production in terms of its effective application in practices, $0.5 \mathrm{~mL}$ of starter $\left(\mathrm{OD}_{600}=1\right)$ was inoc- ulated in each $250 \mathrm{~mL}$ flask containing $50 \mathrm{~mL}$ of NB medium separately supplemented with $0,0.5,1,2,3,4$, and $5 \mathrm{mg}$ $\mathrm{mL}^{-1}$ of L-tryptophan (99\%, ACROS Organics, USA)[26]. The inoculated flasks were incubated at $30^{\circ} \mathrm{C}$ with agitation at $150 \mathrm{rpm}$ for $72 \mathrm{~h} .5 \mathrm{~mL}$ of bacterial culture were adequately withdrawn for each sampling at $0,12,24,36,48$, and $72 \mathrm{~h}$ of incubation. The bacterial growth was measured at $600 \mathrm{~nm}$ of optical density by using the spectrophotometer. For obtaining IAA production, $1.5 \mathrm{~mL}$ of bacterial culture were centrifuged at $10,000 \mathrm{rpm}$ for $10 \mathrm{~min}$ to discard bacterial cells. The IAA concentration was then quantified by the colorimetric method in which $1 \mathrm{~mL}$ of supernatant was added into a $10 \mathrm{~mL}$ tube containing $1 \mathrm{~mL}$ of Salkowski reagent $\left(12 \mathrm{~g} \mathrm{FeCl}_{3}, 1000 \mathrm{~g} 7.9 \mathrm{M} \mathrm{H}_{2} \mathrm{SO}_{4}\right)$ in dark conditions for $30 \mathrm{~min}$ at room temperature. The concentration of IAA was monitored by measuring the optical density at $530 \mathrm{~nm}$ and calculated using a IAA standard curve. $\mathrm{pH}$ of $5 \mathrm{~mL}$ culture samples was also determined by a $\mathrm{pH}$ meter. The experiment was done in triplicate.

\section{Determination of the Optimal Cell Concentration for Bacterial IAA Biosynthesis}

Five hundred microliters of starter in various cell concentrations at $10^{3}, 10^{5}, 10^{7}, 10^{9} \mathrm{CFU} \mathrm{mL} \mathrm{m}^{-1}$ were added into several $250 \mathrm{~mL}$ flasks containing $50 \mathrm{~mL}$ of NB medium supplemented with $5 \mathrm{mg} \mathrm{mL}^{-1}$ L-tryptophan. The inoculated flasks were kept in the incubating shaker with 150 $\mathrm{rpm}$, at $30^{\circ} \mathrm{C}$, for $60 \mathrm{~h}$ in each sampling, $5 \mathrm{~mL}$ of bacterial culture was taken at $0,12,24,36,48$, and $60 \mathrm{~h}$ of incubation. The bacterial growth and IAA production were determined through the above-mentioned methods with three replications.

\section{RESULTS AND DISCUSSION}

\section{A. Optimization of IAA Production of Lysinibacillus Fusiformis UD270}

Lysinibacillus fusiformis UD270 grew rapidly in the first $12 \mathrm{~h}$ and gradually produced IAA over the incubated time. IAA was synthesized in stationary phase of growth as a secondary metabolite which was produced strongly after $24 \mathrm{~h}$. In various amount of tryptophan supplement, the growth and IAA production of the studied endophyte were increased at the high tryptophan concentrations (Figure 1: A, B; Table: 1,2). Similarly, Lysinibacillus fusiformis showed the ability to synthesize IAA with the presence of trypto- 
phan. This bacterium could synthesize IAA from tryptophan as the main precursor [27]. The addition of trypto- phan to the culture medium results in higher IAA production in all studied bacteria [13].
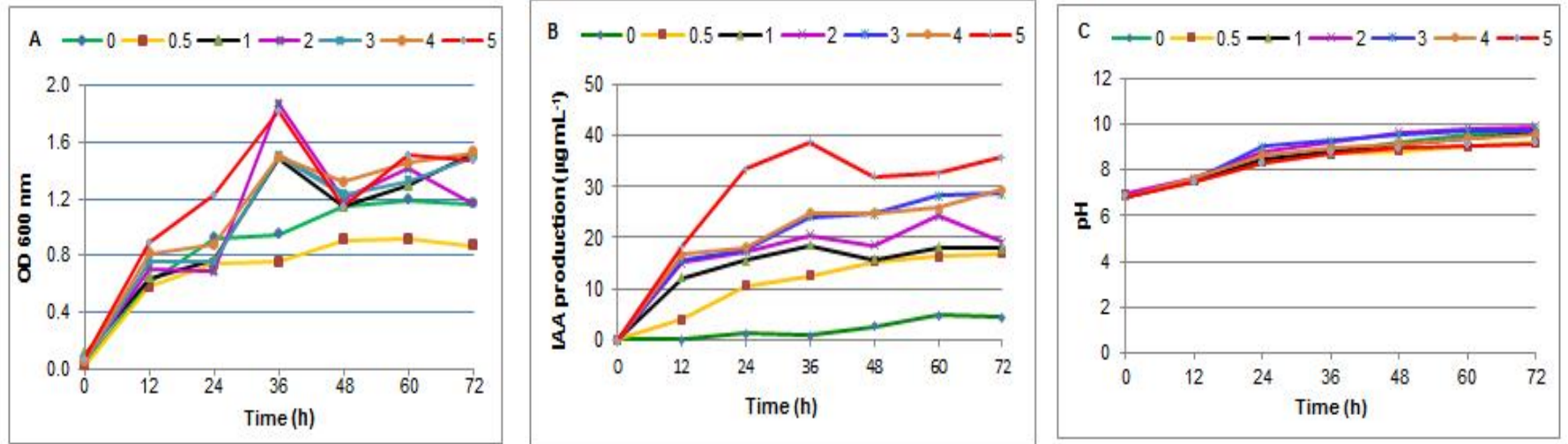

Fig. 1. The growth (A), indole acetic acid production (B) and $\mathrm{pH}(\mathrm{C})$ of L. fusiformis UD270 in nutrient broth with various concentrations of L-tryptophan

TABLE 1

THE GROWTH $\left(\mathrm{OD}_{600} \mathrm{~nm}\right)$ OF L. FUSIFORMIS UD270 IN NUTRIENT BROTH WITH VARIOUS CONCENTRATIONS OF L-TRYPTOPHAN

\begin{tabular}{lccccccc}
\hline \hline Treatment & Time $(\mathrm{h})$ & 0 & 12 & 24 & 36 & 48 & 60 \\
\hline 0 & $0.023 \pm 0.002$ & $0.609 \pm 0.032$ & $0.922 \pm 0.064$ & $0.946 \pm 0.041$ & $1.147 \pm 0.104$ & $1.191 \pm 0.175$ & $1.160 \pm 0.144$ \\
0.5 & $0.021 \pm 0.005$ & $0.578 \pm 0.080$ & $0.740 \pm 0.089$ & $0.749 \pm 0.128$ & $0.908 \pm 0.073$ & $0.917 \pm 0.032$ & $0.867 \pm 0.064$ \\
1 & $0.099 \pm 0.009$ & $0.637 \pm 0.008$ & $0.765 \pm 0.086$ & $1.488 \pm 0.221$ & $1.143 \pm 0.039$ & $1.293 \pm 0.115$ & $1.520 \pm 0.015$ \\
2 & $0.062 \pm 0.015$ & $0.705 \pm 0.093$ & $0.688 \pm 0.004$ & $1.870 \pm 0.017$ & $1.201 \pm 0.040$ & $1.411 \pm 0.355$ & $1.163 \pm 0.045$ \\
3 & $0.046 \pm 0.017$ & $0.761 \pm 0.090$ & $0.750 \pm 0.014$ & $1.498 \pm 0.012$ & $1.230 \pm 0.157$ & $1.325 \pm 0.195$ & $1.496 \pm 0.004$ \\
4 & $0.053 \pm 0.016$ & $0.815 \pm 0.137$ & $0.875 \pm 0.073$ & $1.493 \pm 0.023$ & $1.319 \pm 0.053$ & $1.451 \pm 0.047$ & $1.529 \pm 0.039$ \\
5 & $0.064 \pm 0.007$ & $0.890 \pm 0.106$ & $1.221 \pm 0.079$ & $1.819 \pm 0.080$ & $1.142 \pm 0.069$ & $1.507 \pm 0.190$ & $1.469 \pm 0.210$ \\
\hline \hline
\end{tabular}

TABLE 2

INDOLE ACETIC ACID PRODUCTION ( $\mu \mathrm{g} \mathrm{ml}^{-1}$ ) OF L. FUSIFORMIS UD270 IN NUTRIENT BROTH WITH VARIOUS CONCENTRATIONS OF L-TRYPTOPHAN

\begin{tabular}{|c|c|c|c|c|c|c|c|c|}
\hline Treatments & Time (h) & 0 & 12 & 24 & 36 & 48 & 60 & 72 \\
\hline 0 & & 0.00 & 0.00 & $1.21 \pm 0.013$ & $0.81 \pm 0.019$ & $2.69 \pm 0.020$ & $4.70 \pm 0.015$ & $4.29 \pm 0.009$ \\
\hline 0.5 & & 0.00 & $4.01 \pm 0.008$ & $10.47 \pm 0.026$ & $12.45 \pm 0.050$ & $15.40 \pm 0.013$ & $16.24 \pm 0.008$ & $16.84 \pm 0.045$ \\
\hline 1 & & 0.00 & $12.21 \pm 0.049$ & $15.46 \pm 0.040$ & $18.50 \pm 0.039$ & $15.65 \pm 0.004$ & $18.04 \pm 0.020$ & $17.88 \pm 0.016$ \\
\hline 2 & & 0.00 & $15.10 \pm 0.007$ & $17.20 \pm 0.034$ & $20.38 \pm 0.006$ & $18.41 \pm 0.061$ & $24.29 \pm 0.038$ & $19.09 \pm 0.059$ \\
\hline 3 & & 0.00 & $15.64 \pm 0.005$ & $17.42 \pm 0.045$ & $24.15 \pm 0.037$ & $24.74 \pm 0.011$ & $28.16 \pm 0.010$ & $28.63 \pm 0.019$ \\
\hline 4 & & 0.00 & $16.64 \pm 0.010$ & $18.14 \pm 0.031$ & $24.83 \pm 0.024$ & $24.89 \pm 0.032$ & $25.75 \pm 0.063$ & $29.42 \pm 0.030$ \\
\hline 5 & & 0.00 & $18.30 \pm 0.069$ & $33.44 \pm 0.046$ & $38.68 \pm 0.111$ & $32.03 \pm 0.004$ & $32.60 \pm 0.147$ & $35.77 \pm 0.026$ \\
\hline
\end{tabular}


TABLE 3

THE PH OF L. FUSIFORMIS UD270 IN NUTRIENT BROTH WITH VARIOUS CONCENTRATIONS OF L-TRYPTOPHAN

\begin{tabular}{|c|c|c|c|c|c|c|c|c|}
\hline Treatments & Time (h) & 0 & 12 & 24 & 36 & 48 & 60 & 72 \\
\hline 0 & & 6.93 & 7.48 & 8.45 & 8.83 & 9.2 & 9.57 & 9.69 \\
\hline 0.5 & & 6.92 & 7.49 & 8.34 & 8.68 & 8.81 & 9.03 & 9.18 \\
\hline 1 & & 6.85 & 7.58 & 8.5 & 8.8 & 9.14 & 9.34 & 9.59 \\
\hline 2 & & 6.96 & 7.62 & 8.76 & 9.21 & 9.64 & 9.83 & 9.90 \\
\hline 3 & & 6.82 & 7.57 & 9.04 & 9.26 & 9.54 & 9.69 & 9.71 \\
\hline 4 & & 6.84 & 7.62 & 8.64 & 8.96 & 9.17 & 9.41 & 9.55 \\
\hline 5 & & 6.82 & 7.46 & 8.29 & 8.74 & 8.96 & 9.05 & 9.15 \\
\hline
\end{tabular}

Tryptophan concentrations were set to apply to the practices, varied from 0.5 to $5 \mathrm{mg} \mathrm{mL}^{-1}$. It has been reported that the IAA produced by fluorescent Pseudomonas isolates increased with an increase in concentration of tryptophan from 1 to $5 \mathrm{mg} \mathrm{mL}^{-1}$ [8]. However, IAA production of different $L$. fusiformis endophytic strains was varied from each other. In this present study, the highest level of biosynthetic IAA of $L$. fusiformis UD270 was obtained in $5 \mathrm{mg} \mathrm{mL}^{-1}$ tryptophan at $36 \mathrm{~h}$ of incubation, reaching up to $38.68 \mu \mathrm{g}$ $\mathrm{mL}^{-1}$, followed by $4 \mathrm{mg} \mathrm{mL}^{-1}$ and $3 \mathrm{mg} \mathrm{mL}^{-1}$ tryptophan with $24.83 \mu \mathrm{g} \mathrm{mL}^{-1}$ and $24.15 \mu \mathrm{g} \mathrm{mL}^{-1}$ IAA, respectively (Figure 1B, Table 2). In previous study, L. fusiformis strain ANA81 could significantly produce IAA at $32.12 \mu \mathrm{g} \mathrm{mL}^{-1}$ [23]. In the study of Park et al. [28] IAA production from L. fusiformis isolate PM-5 and PM-24 was $140.9 \mu \mathrm{g} \mathrm{mL}^{-1}$ and $255 \mu \mathrm{g}$ $\mathrm{mL}^{-1}$, respectively, in culture that contained $100 \mathrm{mg} \mathrm{L}^{-1} \mathrm{~L}^{-}$ tryptophan. Thus, in a comparison to others, L. fusiformis UD270 may become a strong candidate for bacterial IAA biosynthesis to function in plant-bacteria interaction. This bacterium was able to produce IAA without tryptophan in an amount of $4.29 \mu \mathrm{g} \mathrm{mL}^{-1}$ at $72 \mathrm{~h}$, while L. fusiformis isolate Ps7 was found as the endophytic plant growth promoting in Prosoposis strombulifera and could produce a small amount of IAA $\left(0.02 \mu \mathrm{g} \mathrm{mL}^{-1}\right)$ in defined media without tryptophan [14]. The $\mathrm{pH}$ of culture was slightly increasing to be alkaline (Figure 1C, Table 3).

It was likely to be the optimum $\mathrm{pH}$ for IAA producing Bacillus spp. which could synthesize the maximum amount of IAA at pH range in 8-9 [10]. Bootkotr and Mongkolthanaruk [25] have found that L. fusiformis UD270 could produce esterase and protease during its growth. The protease of $L$. fusiformis C250R was alkaline and stable in the wide $\mathrm{pH}$ range of 5-10. It might be considered that L. fusiformis tended to adjust $\mathrm{pH}$ of culture to be alkaline for growing and releasing some reasonable metabolites during their growth mechanisms. The alkaline protease might also hydrolyze proteins in the culture and release amino acids, leading to the increase of $\mathrm{pH}$. Moreover, IAA is an uncharged weak acid [29]. Therefore its production might not much affect $\mathrm{pH}$ of culture, causing the $\mathrm{pH}$ of culture depending on growth mechanisms.

The same trend of growth and IAA synthesis was clearly observed when the different cell number was added into culture media containing $5 \mathrm{mg} \mathrm{mL}^{-1}$ L-tryptophan (Figure 2, Tables 4, 5). The cells were varied from $10^{3}$ to $10^{9} \mathrm{CFU}$ $\mathrm{mL}^{-1}$. The bacterial growth in all treatments was rapidly increased at the early incubation, and tendentiously stable after $24 \mathrm{~h}$. The IAA could be synthesized immediately after incubation, particularly with high cell number. It indicated that IAA production increased in the case of increasing tryptophan levels and increasing inoculum size when Burkholderia seminalis was applied to tomato seeds [11]. In present study, the IAA production was increased orderly with increasing cell concentrations in that $10^{7}$ and $10^{9} \mathrm{CFU} \mathrm{mL}^{-1}$ treatments could synthesize IAA faster and in greater quantities than $10^{3}$ and $10^{5} \mathrm{CFU} \mathrm{mL} \mathrm{L}^{-1}$ treatments. IAA was produced quickly and abundantly within $24 \mathrm{~h}$ and stably reached highest amount until $48 \mathrm{~h}$ when it was decreased in all treatments. The biosynthetic IAA was highest at $49.39 \mu \mathrm{g} \mathrm{mL}^{-1}$ in $10^{9} \mathrm{CFU} \mathrm{mL}^{-1}$ experiment (Table 5). As the secondary metabolite, IAA was then increased during the stationary phase and gradually decreased in the later incubation period. The decrease in IAA production might be due to the release of IAA-degrading enzymes such as indole acetic acid oxidase and peroxidase [30]. 

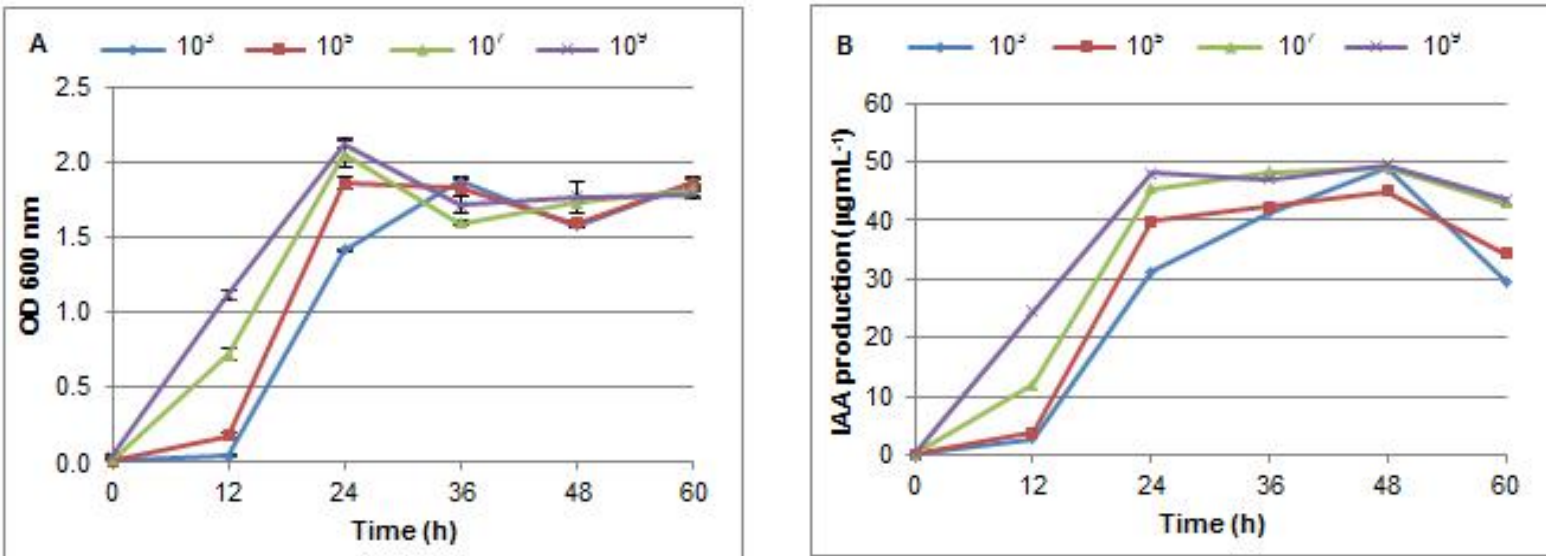

Fig. 2 . The growth (A), indole acetic acid production (B) of L. fusiformis UD270 in nutrient broth with various cell concentrations

TABLE 4

THE GROWTH $\left(\mathrm{OD}_{600} \mathrm{~nm}\right)$ OF L. FUSIFORMIS UD270 IN NUTRIENT BROTH WITH VARIOUS CELL CONCENTRATIONS

\begin{tabular}{|c|c|c|c|c|c|c|c|}
\hline Treatment & Time (h) & 0 & 12 & 24 & 36 & 48 & 60 \\
\hline $10^{3}$ & & $0.007 \pm 0.004$ & $0.042 \pm 0.012$ & $1.416 \pm 0.008$ & $1.878 \pm 0.017$ & $1.580 \pm 0.023$ & $1.867 \pm 0.036$ \\
\hline $10^{5}$ & & $0.012 \pm 0.004$ & $0.179 \pm 0.011$ & $1.862 \pm 0.043$ & $1.827 \pm 0.053$ & $1.593 \pm 0.021$ & $1.854 \pm 0.027$ \\
\hline $10^{7}$ & & $0.012 \pm 0.004$ & $0.716 \pm 0.041$ & $2.052 \pm 0.090$ & $1.596 \pm 0.013$ & $1.727 \pm 0.003$ & $1.817 \pm 0.038$ \\
\hline $10^{9}$ & & $0.041 \pm 0.006$ & $1.118 \pm 0.034$ & $2.126 \pm 0.036$ & $1.711 \pm 0.056$ & $1.766 \pm 0.105$ & $1.782 \pm 0.026$ \\
\hline
\end{tabular}

TABLE 5

INDOLE ACETIC ACID PRODUCTION $\left(\mu \mathrm{g} \mathrm{ml}^{-1}\right)$ OF L. FUSIFORMIS UD270 IN NUTRIENT BROTH WITH VARIOUS CELL CONCENTRATIONS

\begin{tabular}{|c|c|c|c|c|c|c|c|}
\hline Treatments & Time (h) & 0 & 12 & 24 & 36 & 48 & 60 \\
\hline $10^{3}$ & & 0.000 & $2.7 \pm 0.012$ & $31.3 \pm 0.056$ & $41.3 \pm 0.017$ & $48.8 \pm 0.030$ & $29.6 \pm 0.033$ \\
\hline $10^{5}$ & & 0.000 & $3.8 \pm 0.035$ & $40.0 \pm 0.042$ & $42.3 \pm 0.044$ & $45.0 \pm 0.029$ & $34.4 \pm 0.014$ \\
\hline $10^{7}$ & & 0.000 & $12.1 \pm 0.020$ & $45.3 \pm 0.045$ & $48.3 \pm 0.022$ & $49.2 \pm 0.037$ & $43.0 \pm 0.038$ \\
\hline $10^{9}$ & & 0.000 & $24.4 \pm 0.027$ & $48.0 \pm 0.014$ & $47.0 \pm 0.088$ & $49.4 \pm 0.083$ & $43.5 \pm 0.026$ \\
\hline
\end{tabular}

\section{B. The Correlation of Growth and IAA Production of $L$. Fusiformis UD270 in Culture Media}

Since the periodical samples were taken by time, this allowed the correlation between bacterial growth and IAA biosynthesis to be obtained. The correlation was displayed in Figure 3. In the two experiments in which tryptophan concentration and cell number were the main factors, a positive correlation between growth and IAA production was found. In detail, when varying the concentration of tryptophan added in culture media, the bacteria grew and synthesized IAA with the same tendency, showing the significant positive correlation between growth and IAA production with correlation coefficient $r=0.773$ at $p<0.05$
(Figure 3A, Table 6). The similar observation was indicated in treatments that had different cell number amounts. The positive relationship between these two experimental parameters was also strongly indicated with $r=0.974$ at $p<$ 0.05 (Figure 3B, Table 7).

There were three factors that can affect growth as well as IAA synthesis such as carbon limitation, reduction in growth rate and concentration of substrate for IAA production [31]. In the present study, although the concentration of tryptophan was varied from lower to higher levels, it might be beneficial to compare to those used for synthesizing IAA process. Therefore, the bacteria could use the precursor to synthesize IAA abundantly together with increasing biomass during incubating time. Moreover, when 
different inoculum concentrations as various amounts of IAA producer were added into culture media, the growth and IAA production depended on the number of inoculated cells (Figure 2). It also means that, at the higher amount of IAA producer, the growth and IAA production might be greater than at lower amounts. The increase of growth is inversely linked to the increase of IAA production. This tendency indicated a positive correlation.
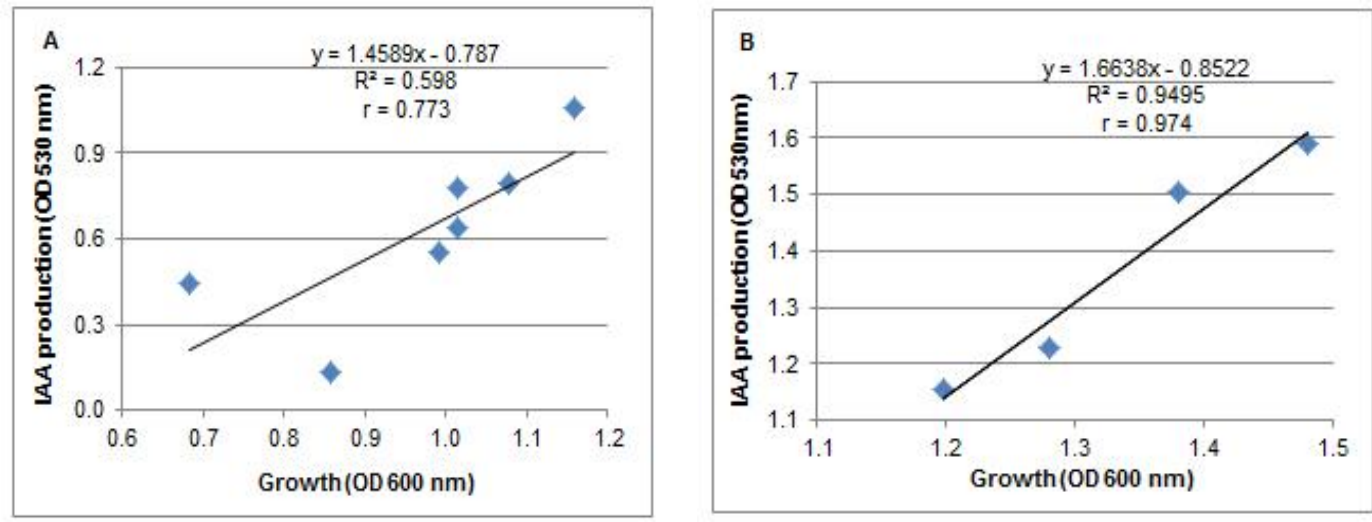

Fig. 3 . The correlation between growth and indole acetic acid production in various concentrations of tryptophan (A) and different cell number (B) experiments of L. fusiformis UD270

TABLE 6

THE CORRELATION BETWEEN GROWTH AND INDOLE ACETIC ACID PRODUCTION IN VARIOUS CONCENTRATIONS OF TRYPTOPHAN EXPERIMENTS OF L. FUSIFORMIS UD270

\begin{tabular}{llcc}
\hline \hline \multirow{4}{*}{ Growth } & Growth & IAA \\
\cline { 2 - 3 } & Pearson correlation & 1 & $0.773^{*}$ \\
& Sig. (2-tailed) & & 0.041 \\
IAA & $N$ & 7 & 7 \\
& Pearson correlation & $0.773^{*}$ & 1 \\
& Sig. (2-tailed) & 0.041 & \\
& $N$ & 7 & 7 \\
\hline *Correlation is significant at the 0.05 level (2-tailed)
\end{tabular}

TABLE 7

THE CORRELATION BETWEEN GROWTH AND INDOLE ACETIC ACID PRODUCTION IN DIFFERENT CELL NUMBER EXPERIMENTS OF $L$. FUSIFORMIS UD270

\begin{tabular}{llcc}
\hline \hline & & Growth & IAA \\
\hline \multirow{4}{*}{ Growth } & Pearson correlation & 1 & $0.974^{*}$ \\
& Sig. (2-tailed) & & 0.026 \\
\multirow{4}{*}{ IAA } & $N$ & 4 & 4 \\
& Pearson correlation & $0.974 *$ & 1 \\
& Sig. (2-tailed) & 0.026 & \\
& $N$ & 4 & 4 \\
\hline *Correlation is significant at the 0.05 level (2-tailed)
\end{tabular}




\section{CONCLUSION}

The endophyte L. fusiformis strain UD270 has shown the ability to synthesize IAA in the medium supplemented with L-tryptophan. Moreover, the different sizes of inoculum cell concentration lead to variable growth and IAA production for each concentration. In terms of effective application, the best growth and IAA production were determined by the suitable concentration of L-tryptophan and the amount of inoculum for IAA production which were $5 \mathrm{mg}$ $\mathrm{mL}^{-1}$ and $10^{9} \mathrm{CFU} \mathrm{mL} \mathrm{m}^{-1}$, respectively, pointing to a positive correlation between these two parameters. This IAA producing bacteria should be utilized to improve its potential capacity involving plant-bacteria interaction in further research.

\section{ACKNOWLEDGEMENT}

The authors thank to KKU Scholarship for ASEAN and GMS countrie's Personel, Academic Year 2015, Graduated School, and Salt-tolerant Rice Research Group, Khon Kaen University, Thailand for the financial support.

\section{REFERENCES}

[1] B. R. Glick, "Plant growth-promoting bacteria: Mechanisms and applications," Scientifica, vol. 20, no. 1, pp 1-15, 2012. DOI: 10.6064/2012/963401

[2] P. F. O'Connell, "Sustainable agriculture-a valid alternative," Outlook on Agriculture, vol. 21, no. 1, pp. 5-12, 1992. DOI: $10.1177 / 003072709202100103$

[3] A. Esitken, H. E. Yildiz, S. Ercisli, M. Figen Donmez, M. Turan and A. Gunes, "Effects of Plant Growth Promoting Bacteria (PGPB) on yield, growth and nutrient contents of organically grown strawberry," Scientia Horticulturae, vol. 124 , no. 1, pp. 62-66, 2010.

DOI: $10.1016 /$ j.scienta.2009.12.012

[4] C. R. Sari, J. Taylor, Y. Hong and S. Jackson, "Development of a transient viral CRISPR expression system to manipulate flowering time in plants," International Journal of Applied and Physical Sciences, vol. 2, no. 3, pp. 65-70, 2016. DOI: 10.20469 /ijaps.2.50002-3

[5] D. Egamberdiyeva, "Plant-growth-promoting rhizobacteria isolated from a calcisol in a semi-arid region of Uzbekistan: Biochemical characterization and effectiveness," Journal of Plant Nutrition and Soil Science, vol. 168, no. 1, pp. 94-99, 2005.

DOI: $10.1002 /$ jpln.200321283

[6] M. Miransari and D. L. Smith, "Plant hormones and seed germination," Environmental and Experimental Botany, vol. 99, pp. 110-121, 2014.

DOI: $10.1016 /$ j.envexpbot.2013.11.005

[7] J. Vessey, "Plant growth promoting rhizobacteria as biofertilizers," Plant and Soil, vol. 255, no. 2, pp. 571-586, 2003. DOI: 10.1023/A:1026037216893

[8] F. Ahmad, I. Ahmad and M. S. Khan, "Indole acetic acid production by the indigenous isolates of Azotobacter and fluorescent Pseudomonas in the presence and absence of tryptophan," Turkish Journal of Biology, vol. 29, no. 1, pp. 29-34, 2005.

[9] U. Bharucha, K. Patel and U. B. Trivedi, "Optimization of indole acetic acid production by Pseudomonas putida UB1 and its effect as plant growth-promoting rhizobacteria on mustard (Brassica nigra)," Agricultural Research, vol. 2, no. 3, pp. 215-221, 2013.

DOI: $10.1007 / \mathrm{s} 40003-013-0065-7$

[10] B. Mohite, "Isolation and characterization of Indole Acetic Acid (IAA) producing bacteria from rhizospheric soil and its effect on plant growth," Journal of Soil Science and Plant Nutrition, vol. 13, no. 3, pp. 638-649, 2013. DOI: $10.4067 / S 0718-95162013005000051$

[11] P. Tallapragada, R. Dikshit and S. Seshagiri, "Isolation and optimization of IAA produce Burkholderia seminalis and its effect on seedlings of tomato," Songklanakarin Journal of Science \& Technology, vol. 37, no. 5, pp. 553-559, 2015.

[12] R. T. Vendan, Y. J. Yu, S. H. Lee and Y. H. Rhee, "Diversity of endophytic bacteria in ginseng and their potential for plant growth promotion," Journal of Microbiology, vol. 48 , no. 5, pp. 559-565, 2010.

DOI: $10.1007 / \mathrm{s} 12275-010-0082-1$

[13] W. J. Kim and H. G. Song, "Interactions between biosynthetic pathway and productivity of IAA in some rhizobacteria," The Korean Journal of Microbiology, vol. 48, no. 1, pp. 1-7, 2012. DOI: 10.7845/kjm.2012.48.1.001

[14] V. Sgroy, F. Cassán, O. Masciarelli, M. F. Del Papa, A. Lagares and $\mathrm{V}$. Luna, "Isolation and characterization of endophytic Plant Growth-Promoting (PGPB) or Stress Homeostasis-Regulating (PSHB) bacteria associated to the halophyte Prosopis strombulifera," Applied Microbiology and Biotechnology, vol.85, no. 2, pp. 371-381, 2009. DOI: $10.1007 / s 00253-009-2116-3$ 
[15] J. M. Lynch and J. M. Whipps, "Substrate flow in the rhizosphere," Plant and Soil, vol. 129, no. 1, pp. 1-10, 1990. DOI: $10.1007 / \mathrm{bf00011685}$

[16] V. Chernenok, A. Kurishbayev, A. Kudashev and Y. Nurmanov, "Diagnostics and optimization of crops' nitrogen nutrition in rainfed conditions of the Northern Kazakhstan," Journal of Applied and Physical Sciences, vol. 1, no. 1. pp. 1-8, 2015. DOI: 10.20474/-japs1.1.1

[17] M. B. Yusuf, B. M. Firuza and O. S. Khairulmaini, "Variation in soil physiochemical properties at different land use sites in Northeastern Nigeria," International Journal of Applied and Physical Sciences, vol. 3, no. 1, pp. 26-34, 2017. DOI: 10.20469 /ijaps.3.50004-1

[18] J. Hallmann, A. Quadt-Hallmann, W. F. Mahaffee and J. W. Kloepper, "Bacterial endophytes in agricultural crops," Canadian Journal of Microbiology, vol. 43, no. 10, pp. 895-914, 1997. DOI: $10.1139 / \mathrm{m} 97-131$

[19] A. V. Sturz, B. R. Christie and J. Nowak, "Bacterial endophytes: potential role in developing sustainable systems of crop production," Critical Reviews in Plant Sciences, vol. 19, no. 1, pp. 1-30, 2000.

DOI: $10.1080 / 07352680091139169$

[20] J. Davison, "Plant beneficial bacteria," Nature Biotechnology, vol. 6, no. 3, pp. 282-286, 1988.

DOI: $10.1038 / \mathrm{nbt} 0388-282$

[21] J. W. Kloepper, R. Lifshitz and R. M. Zablotowicz, "Freeliving bacterial inocula for enhancing crop productivity," Trends in Biotechnology, vol. 7, no. 2, pp. 39-44, 1989. DOI: 10.1016/0167-7799(89)90057-7

[22] S. N. Jones and E. A. Bergey, "Habitat segregation in stream crayfishes: Implications for conservation," Journal of the North American Benthological Society, vol. 26, no. 1, no. 134-144, 2007.

DOI: $10.1899 / 0887-3593(2007) 26[134:$ hsisci]2.0.co;2

[23] P. Trivedi, T. Spann and N. Wang, "Isolation and characterization of beneficial bacteria associated with citrus roots in Florida," Microbial Ecology, vol. 62, no. 2, pp. 324-336, 2011. DOI: 10.1007/s00248-011-9822-y

[24] R. L. Melnick, C. Suárez, B. A. Bailey and P. A. Backman, "Isolation of endophytic endospore-forming bac- teria from Theobroma cacao as potential biological control agents of cacao diseases," Biological Control, vol. 57, no. 3, pp. 236-245, 2011.

DOI: $10.1016 /$ j.biocontrol.2011.03.005

[25] W. Bootkotr and W. Mongkolthanaruk, "Properties of bacteria beneficial to the promotion of plant growth, "

in Proceedings of Ponencia presentada en: International Conference on Life Science \& Biological Engineering, Singapur, 2012.

[26] Fisher Scientific, "L-5-Hydroxytryptophan, 99\%, ACROS organics," n.a. [Online]. Available from: goo.gl/JpGt2o

[27] S. Spaepen and J. Vanderleyden, "Auxin and plantmicrobe interactions," Cold Spring Harbor Perspectives in Biology, vol. 3, no. 4, pp. 1-13, 2011.

DOI: $10.1101 /$ cshperspect.a001438

[28] M. Park, C. Kim, J. Yang, H. Lee, W. Shin, S. Kim and T. Sa, "Isolation and characterization of diazotrophic growth promoting bacteria from rhizosphere of agricultural crops of Korea," Microbiological Research, vol. 160, no. 2, pp. 127-133, 2005.

DOI: $10.1016 /$ j.micres.2004.10.003

[29] A. Kumar, A. Srivastava, I. Y. Galaev and B. Mattiasson, "Smart polymers: Physical forms and bioengineering applications," Progress in Polymer Science, vol. 32, no. 10, pp. 1205-1237, 2007.

DOI: $10.1016 /$ j.progpolymsci.2007.05.003

[30] V. Jeyanthi and P. Ganesh, "Production, optimization and characterization of phytohormone indole acetic acid by pseudomonas fluorescence," International Journal of Pharmaceutical \& Biological Archives, vol. 4, no. 2, pp. 514-520, 2013.

[31] S. Spaepen, J. Vanderleyden and R. Remans, "Indole3-acetic acid in microbial and microorganism-plant signaling," FEMS Microbiology Reviews, vol. 31, no. 4, pp. 425-448, 2007.

DOI: $10.1111 / \mathrm{j} .1574-6976.2007 .00072 . \mathrm{x}$ 